\title{
PEMANFAATAN GOOGLE MAPS SEBAGAI ALTERNATIF MEDIA PELESTARIAN BENDA PENINGGALAN SEJARAH DI KOTA SEMARANG
}

\author{
Ibnu Sodiq \\ Email : faqihfaruq01@gmail.com \\ Jurusan Sejarah Universitas Negeri Semarang
}

\begin{abstract}
Abstrak
Permasalahan utama dalam penelitian ini adalah belum adanya model konservasi cagar budaya yang terjadi dengan cepat dan mudah bagi masyarakat sebagai prasyarat konservasi peninggalan sejarah di Kota Semarang. Secara lebih spesifik dan operasional, permasalahan penelitian dirumuskan sebagai berikut. 1) Bagaimana pengembangan prototype menjadi model system informasi untuk cagar budaya yang ada di Kota Semarang?. Penelitian ini dilakukan dengan menggunakan pendekatan Penelitian Pengembangan (Research and Development).Saat ini, Kota Semarang memiliki 14 kawasan cagar budaya. Ke empat belas kawasan tersebut meliputi, (1) Kawasan Kota Lama; (2) Kawasan Petudungan; (3) Kawasan Kampung Kulitan; (4) Kawasan Kampung Batik; (5) Kawasan Pecinan; (6) Kawasan Johar; (7) Kawasan Kampung Melayu; (8) Kawasan Kampung Kauman; (9) Kawasan Tugu Muda; (10) Kawasan Kampung Senjoyo; (11) Kawasan Sam Po Kong, (12) Kawasan Perumahan PJKA di Kedungjati; (13) Kawasan Makam Sunan Terboyo; dan (14) Kawasan Kampung Sekayu. 2. Upaya pengembangan model konservasi cagar budaya dilakukan dengan menguatkan aspek pengetahuan masyarakat. Dengan demikian, penguatan konservasi diterapkan dengan berbasis literasi informasi. Penguatan ini dilakukan dengan mengintegrasikan informasi kesejarahan di aplikasi Google Maps. Penggunaan Google Maps dilakukan agar masyarakat dengan mudah mengakses informasi kesejarahan dan arti penting cagar budaya di Kota Semarang.
\end{abstract}

Kata Kunci: Google Maps, Alternatif Media, Konservasi, Peninggalan Sejarah

\section{Pendahuluan}

Benda-benda cagar budaya merupakan kekayaan budaya bangsa yang penting artinya bagi pemahaman dan pengembangan sejarah ilmu pengetahuan dan kebudayaan, sehingga perlu dilindungi dan dilestarikan demi pemupukan kesadaran jatidiri bangsa dan kepentingan nasional (Tjandrasasmita, 2010). Secara lebih rinci, Tanudirjo (2003) menguraikan bahwa ada beberapa dimensi dalam melihat arti penting cagar budaya, yakni dimensi pengetahuan, etnik, estetik, dan publik. Dalam dimensi pengetahuan, cagar budaya dijadikan sebagai media pengajian dan pengujian akademik. Dalam dimensi etnik, cagar budaya berposisi sebagai bagian dari jati diri dan latar kehidupan suatu bangsa. Ditinjau dari segi estetik, cagar budaya merupakan bukti hasil seni yang adiluhung. Kemudian ditinjau dari segi public, cagar 
budaya memiliki nilai pendidikan untuk masyarakat, sebagai daya tarik wisata, serta warana untuk mendapatkan keuntungan secara ekonomis.

Salah satu kota yang memiliki beragam cagar budaya adalah Kota Semarang. Kota Semarang memiliki beberapa kawasan yang strategis untuk dijadikan kawasan konservasi. Kota Lama, daerah Pecinan, Pasar Johar, dan Kampung Sekayu merupakan kawasan bersejarah yang harus dikonservasi (Hendro, 2015). Bahkan, berdasarkan Peraturan Daerah Kota Semarang Nomor 14 Tahun 2011 tentang Rencana Tata Ruang Wilayah Kota Semarang Tahun 2011-2031, Kota Semarang memiliki 14 kawasan cagar budaya. Ke empat belas kawasan tersebut meliputi, (1) Kawasan Kota Lama; (2) Kawasan Petudungan; (3) Kawasan Kampung Kulitan; (4) Kawasan Kampung Batik; (5) Kawasan Pecinan; (6) Kawasan Johar; (7) Kawasan Kampung Melayu; (8) Kawasan Kampung Kauman; (9) Kawasan Tugu Muda; (10) Kawasan Kampung Senjoyo; (11) Kawasan Sam Po Kong, (12) Kawasan Perumahan PJKA di Kedungjati; (13) Kawasan Makam Sunan Terboyo; dan (14) Kawasan Kampung Sekayu.

Namun demikian, berdasarkan penelitian dari Widiastuti (2014) ternyata ada permasalahan dalam penangangan cagar budaya di Semarang. Di Kota lama, misalnya, saat ini kondisinya sangat memprihatinkan, tidak terawat, bahkan terkesan kumuh, pada hal kota lama menyimpan potensi yang sangat besar baiksebagai wisata, sumber belajar dan pengembangan ilmu pengetahuan dan budaya. Berdasarkan kajian Bapeda selama kurun waktu sepuluh tahun belakangan ini sudah 18 bangunan cagar budaya yang hilang.

Permasalahan ini menjadi penguat pentingya konservasi terhadap cagar budaya di Kota Semarang. Menurut Undang-Undang Nomor 11 tahun 2010, pelestarian merupakan upaya dinamis untuk mempertahankan keberadaan Cagar Budaya dan nilainya dengan cara melindungi, mengembangkan, dan memanfaatkannya. Hendro (2015) menyatakan bahwa konservasi kawasan diperlukan untuk memberikan perlindungan kawasan-kawasan tersebut dari gencarnya pembangunan kota, termasuk mengendalikan perkembangan kawasan tersebut agar tidak hilang identitas kesejarahaan dan kebudayaannya.

Secara umum, pelestarian budaya dapat dikategorikan menjadi dua kelompok. Pertama, culture experience yaitu pelestarian budaya dengan terjun langsung di tempat kejadian. Kedua, culture knowledge yaitu pelestarian budaya dengan cara membuat sebuah pusat informasi mengenai kebudayaan yang dapat difungsionalisasi dalam berbagai bentuk. Dari kedua bentuk pelestarian tersebut, pelestarian budaya berupa culture knowledge adalah 
bentuk pelestarian budaya yang lebih efektif untuk dilakukan. Dinyatakan demikian karena lingkup pelestarian yang dilakukan tidak terfokus pada satu pelestarian budaya, dan mencakup sebagian besar budaya yang harus dilestarikan (Hastuti \& hidayat, 2014).

Salah satu strategi pendokumentasian dan publikasi yang mudah diakses secara luas adalah sistem informasi. Melalui sistem informasi, berbagai data tentang cagar budaya akan dimunculkan, sehingga masyarakat memiliki pengetahuan yang cukup terhadap cagar budaya di Kota Semarang. Dengan demikian, pengembangan sistem informasi ini diharpakan mampu memberi pemahaman kepada masyarakat untuk berpartisipasi dalam melestarikan cagar budaya di Kota Semarang.

Permasalahan utama dalam penelitian ini adalah belum adanya model konservasi cagar budaya yang terjadi dengan cepat dan mudah bagi masyarakat sebagai prasyarat konservasi peninggalan sejarah di Kota Semarang. Secara lebih spesifik dan operasional, permasalahan penelitian dirumuskan sebagai berikut. 1) Bagaimana pengembangan prototype menjadi model system informasi untuk cagar budaya yang ada di Kota Semarang?

\section{Metode}

Penelitian ini dilakukan dengan menggunakan pendekatan Penelitian Pengembangan (Research and Development). Menurut Borg and Gall (1989:782), yang dimaksud dengan model penelitian dan pengembangan adalah a process used develop and validate educational product. Selain untuk mengembangkan dan memvalidasi hasil-hasil pendidikan, penelitian jenis ini juga bertujuan untuk menemukan pengetahuan-pengetahuan baru melalui penelitian dasar, atau untuk menjawab pertanyaan-pertanyaan khusus tentang masalah-masalah yang bersifat praktis melalui penelitian terapan, yang digunakan untuk meningkatkan praktikpraktik pendidikan. Dalam penelitian ini Research and Development dimanfaatkan untuk menghasilkan 11ystem informasi cagar budaya di Kota Semarang. Sumber data meliputi informan : (1) peninggalan atau cagar budaya di Kota Semarang sebagai objek utama penelitian; (2) ahli teknologi informasi sejarah serta sejarawan yang terlibat dalam uji validasi isi dan media; (3) para stakeholders (yang meliputi masyarakat dan pemerintah kota Semarang).

\section{Hasil dan Pembahasan}




\section{Identifikasi Kawasan Peninggalan Sejarah}

Semarang adalah ibu kota provinsi Jawa Tengah dan saat ini berfungsi sebagai pusat pemberintahan, industri, perdagangan, pendidikan, dan pariwisata. Secara geografi, Semarang terletak di Pantai utara pulau Jawa dan terletak di garis 6.30`7.10` lintang selatan dan 109.50`110.35 bujur timur dan dengan luas wilayah $373,73 \mathrm{~km} 2$. Suhu udara rata-rata adalah antara 240-320c, dengan curah hujan per tahun adalah sekitar $2000 \mathrm{~mm}$ dan kelembapan seitar 77\%. Ketinggian tanah dari permukaan air laut adalah sekitar 0,75 m-350 m dan dibagi menjadi dua bagian, yaitu Semarang Candi berada di daerah selatan kota semarang yang saat ini berkembang sebagai tempat tinggal dan semarang kota bawah yang digunakan sebagai daerah perdagangan.

Berdasarkan sejarahnya, kota Semarang memiliki suatu kawasan yang ada pada sekitar abad 18 menjadi pusat perdagangan. Kawasan tersebut pada masa sekarang disebut Kawasan Kota Lama. Pada masa itu, untuk mengamankan warga dan wilayahnya, maka kawasan itu dibangun benteng, yang dinamai benteng Vijhoek.Untuk mempercepat jalur perhubungan antar ketiga pintu gerbang dibenteng itu maka dibuat jalan-jalan perhubungan, dengan jalan utamanya dinamai Heeren Straat. Saat ini bernama Jl. Let Jen Soeprapto.Salah satu lokasi pintu benteng yang ada sampai saat ini adalah Jembatan Berok, yang disebut DE ZUIDER POR.

Kawasan Kota Lama Semarang disebut juga outstadt. Luas kawasan ini sekitar 31 Hektar. Dilihat dari kondisi geografi, nampak bahwa kawasan ini terpisah dengan daerah sekitarnya, sehingga nampak seperti kota tersendiri, sehingga mendapat julukan "Little Netherland".

Kawasan Kota Lama Semarang ini merupakan saksi bisu sejarah Indonesia masa kolonial Belanda lebih dari 2 abad, dan lokasinya berdampingan dengan kawasan ekonomi. Ditempat ini ada sekitar 50 bangunan kuno yang masih berdiri dengan kokoh dan mempunyai sejarah Kolonialisme di Semarang. Kota Lama Semarang ini adalah daerah yang bersejarah dengan banyaknya bangunan kuno yangdinilai sangat berpotensi untuk dikembangkan dibidang kebudayaan ekonomi serta wilayah konservasi.

Berdasarkan SK Walikota N0. 646/50/1992 atau Perda No.640 Tahun 2003 tentang RTBL Kawasan Kota Lama Semarang, benda cagar budaya di Kota Semarang sebanyak 328 buah meliputi bangunan sosial budaya seperi sekolah, bangunan kesehatan/rumah sakit, kantor pos dan kantor pelayanan, gedung serba guna, stasiun, museum, lain-lain. Selain itu ada pula bangunan keagamaan, seperti masjid/mushola, gereja, serta klenteng. Ada pula bangunan yang termasuk dalam bangunan usaha seperti perkantoran, pabrik dan gudang, hotel/penginapan, 
gedung pertemuan, restoran, serta pasar. Namun demikian, banyak pula bangunan cagar budaya yang termasuk dalam bangunan hunian serta bangunan khusus, seperti reservoir, gerbang, gardu listrik, taman dan sebagainya. Bangunan-bangunan yang tergologn sebagai benda cagar budaya dan dilindungi oleh undang-undang tersebut tersebar di beberapa kawasan di Kota Semarang, seperti kota lama, Pecinan, Jalan Petudungan, Kampung Kulitan, kawasan Tugu Muda, Taman Diponegoro, Perumahan PJKA (Gergadji Wooning Park), Kampung Melayu, Kampung Kauman, Kampung Mlaten, Perumahan Sompok, Kampung Karangdara, kawasan Candi, dan sebagainya.

Saat ini, Kota Semarang memiliki 14 kawasan cagar budaya. Ke empat belas kawasan tersebut meliputi, (1) Kawasan Kota Lama; (2) Kawasan Petudungan; (3) Kawasan Kampung Kulitan; (4) Kawasan Kampung Batik; (5) Kawasan Pecinan; (6) Kawasan Johar; (7) Kawasan Kampung Melayu; (8) Kawasan Kampung Kauman; (9) Kawasan Tugu Muda; (10) Kawasan Kampung Senjoyo; (11) Kawasan Sam Po Kong, (12) Kawasan Perumahan PJKA di Kedungjati; (13) Kawasan Makam Sunan Terboyo; dan (14) Kawasan Kampung Sekayu.

\section{Analisis Kebutuhan dan Keterlibatan Masyarakat dalam Konservasi Cagar Budaya}

Dari wawancara yang dilakukan terhadap beberapa masyarakat di Kota Semarang dan Surakarta, ternyata ada berbagai macam patisipasi yang dilakukan oleh maysarakat dalam rangka pelestarian bagunan cagar budaya yang ada di kotanya. Wawancara yang dilakukan terhadap beberapa informan menyatakan bahwa mereka tidak dapat melakukan secara langusng upaya pelestarian terhadap bangunan cagar budaya.

Upaya yang dilakukan oleh masyarakat adalah dalam bentuk sumbangan pemikiran yang dituangkan melalui tulisan. Hal ini pulalah yang menjadi salah satu aspek yang melatarbelakangi dirilisnya beberapa website atau blog di internet yang mengulas berbagai hal tentang bangunan cagar budaya, seperti situs http://kabutinstitut.blogspot.com, http://kurakurabiru.multiply.com, situs yang dirilois oleh kabut institut dan berbagai situs di internet lainnya yang menandakan tingkat kepedulian tinggi dari masyarakat perkotaan terhadap pelestarian bangunan cagar budaya. Selain partisipasi masyarakat dalam kegiatan pelestarian melalui dunia maya, ada pula partispasi masyarakat dalam bentuk kelompok. Kelompok masyarakat tersebut terdiri atas beberapa orang yang peduli akan pelestarian bangunan cagar budaya. Biasanya mereka membuat semacam lembaga swadaya masyarakat. Beberapa kelompok yang memiliki kepedulian tersebut 
antara lain Kopi Semawis, (Komunitas Pecinan Semarang Wisata), Sahabat Warisan Budaya dan sebagainya.

Di Kota Semarang terdapat pula LSM yang bernama Sahabat Warisan Budaya. LSM Ini berawal dari pengiriman 19 orang yang berasal dari Pemda, swasta, dan perguruan tinggi ke Belana selama dua bulan untuk mengikuti kegiatan short course tentang intercity criteria. LSM ini dibentuk pada tahun 2000. Kegiatan yang pernah dilakukan dalam rangka nguri-uri kota lama semarang antaralain mengadakan acara konser musik bertajuk 'Denting Dawai Kota Tua' sebagai apresiasi terhadap kota lama Semarang,

Kesadaran masyarakat perkotaan dalam pelestarian bangunan cagar budaya memang tidak serta merta dilakukan oleh sumua kalangan masyarkat. Sebagian masyarakat yang memang benar-benar peduli terhadap pelestarian bangunan budaya dari penelitian yang dilakukan memang berasal dari kalangan masyarakat yang memiliki pendidikan yang cukup serta memiliki penghasilan yang cukup.

Dari hasil penelitian ada beberapa jenis partisipasi masyarakat perkotaan terhadap pelestarian bangunan cagar budaya. Partisipasi yang dilakukan oleh masyarakat perkotaan berdasarkan hasil penelitian dapat dibedakan menjadi dua, yakni partisipasi yang dilakukan secara passif dan partisipasi yang dilakukan secara aktif. Partisipasi yang dilakukan secara aktif oleh masyarakat biasanya dilakukan dalam bentuk perlindungan terhadap bangunan cagar budaya melalui kegiatan penyelamatan, pengamanan, sampai dengan pembinaan. Selain itu dilakukan pula upaya untuk melakukan pengembangan, seperti pemberdayaan kembali bangunan lama, serta pemanfaatan bangunan untuk kepentingan pendidikan, pariwisata dalam bentuk festival, pekan budaya, dan sebagainya. Pada beberapa wilayah di Kota Lama Semarang pemanfaatan bangunan lama dilakukan sebagai salah satu tempat usaha. Hal ini dapat dilakukan selama tidak mengurangi makna nilai sejarah bangunan tersebut.

Partisipasi aktif yang dilakukan oleh masyarakat biasanya dilakuan terhadap bangunanbangunan yang sampai sekarang masih memiliki makna bagi masyarakat dan bersifat sebagai tempat yang masih dapat dimanfaatkan. Berbagai bangunan cagar budaya yang tergolong dalam kriteria ini antara lain tempat ibadah serta bangunan-bangunan sosial budaya seperti sekolah. Partisipasi aktif masyarakat untuk melestarikan bangunan tersebut dikarenakan sampai sekarang masyarkat masih memanfaatkan bangunan tersebut untuk aktiviasnya, sehingga mereka merasa memiliki bangunan tersebut. Rasa memiliki dari bangunan dan nilai kebermanfaatan yang 
terkandung di dalamnya inilah yang menjadi salah satu landasan bagi masyarakat untuk senantiasa melakukan pelestarian terhadap bangunan cagar budaya.

Selain partisipasi aktif yang dilakukan oleh masyarakat, ada pula partisipasi pasif dalam rangka pelestarian bangunan cagar budaya. Pelestarian secara pasif yang dimaksud dalam penelitian ini adalah upaya tidak langsung yang dilakukan oleh masyarakat yang mendukung pelestarian bangunan cagar budaya. Upaya pasif ini dilakukan dengan cara melakukan kunjungan ataupun dengan tidak melakukan aktivitas yang dapat mengurangi makna dari bangunan cagar budaya tersebut. Alasan yang dikemukakan oleh para informan untuk memilih partisipasi secara pasif ini adalah karena selain kendala dari aspek intern, yakni keterbatasan akses, kemampuan, dan waktu untuk melakukan pelestarian secara aktif, juga dikarenakan adanya keterbatasan wewenang dari masyarakat untuk melakukan kegiatan pelestarian. Dengan demikian, pilihan yang diambil oleh mereka adalah dengan tidak melakukan kegiatan yang merugikan, melakukan kegiatan kunjungan, serta memberikan perhatian terhadap bangunan cagar budaya tersebut.

Masih belum banyaknya upaya yang dilakukan dalam pelestarian bangunan cagar budaya dikarenakan adanya beberapa kendala dari aspek ekstern. Beberapa hal yang turut menjadi kendala dalam pelestarian bangunan cagar budaya ini bahwa masyarakat merasa bahwa tidak memiliki kewenangan yang cukup dalam pelestarian bangunan cagar budaya, sehingga partisipasi yang diberikan adalah partisipasi secara pasif, yakni melalui sumbangan pemikiran dalam media massa, ataupun hanya sekadar melakukan kunjungan, serta dengan tidak melakukan aktivitas yang merusak bangunan cagar budaya tersebut. Sementara itu, kendala ekstern yang ditemui organisasi yang memiliki kepedulian dalam pelstarian cagar budaya adalah bahwa mereka tidak memiliki pendanaan yang cukup dalam menjalankan aktivitasnya, sehingga aktivitas yang dilakuan berkesan insidental.

Oleh karena itu, partisipasi masyarakat dalam pelestarian bangunan cagar budaya bukan menjadi hal yang utama, melainkan menjadi satu mata rantai dari sinergitas segala komponen dalam pelestarian banguanan cagar budaya. Hal ini dikarenakan pelestarian bangunan cagar budaya membutuhkan perhatian tidak hanya dari masyarakat saja, tetapi dari pemerintah, masyarakat, stakeholder, serta pemilik dari bangunan cagar budaya tersebut. Dari berbagai penjelasan di atas, ternyata partisipasi masyarakat dalam pelestarian dan konservasi peninggaan sejarah masih minim. Oleh karena itu, perlu adanya upaya untuk mengembangkan model 
pelestarian cagar budaya. Salah satu prioritas yang kami lakukan adalah dengan menguatkan aspek teknologi informasi.

\section{Model Pelestarian Peninggalan Sejarah di Kota Semarang}

Model pelestarian cagar budaya dilakukan dengan mengintegrasikan antara teks dan aplikasi. Dalam hal ini digunakan aplikasi Google Maps. Google Maps adalah layanan pemetaan web yang dikembangkan oleh Google. Layanan ini memberikan citra satelit, peta jalan, panorama $360^{\circ}$, kondisi lalu lintas, dan perencanaan rute untuk bepergian dengan berjalan kaki, mobil, sepeda (versi beta), atau angkutan umum.

Google Maps dimulai sebagai program desktop $\mathrm{C}++$, dirancang oleh Lars dan Jens Eilstrup Rasmussen pada Where 2 Technologies. Pada Oktober 2004, perusahaan ini diakuisisi oleh Google, yang diubah menjadi sebuah aplikasi web. Setelah akuisisi tambahan dari perusahaan visualisasi data geospasial dan analisis lalu lintas, Google Maps diluncurkan pada Februari 2005. Layanan ini menggunakan Javascript, XML, dan AJAX. Google Maps menawarkan API yang memungkinkan peta untuk dimasukkan pada situs web pihak ketiga, dan menawarkan penunjuk lokasi untuk bisnis perkotaan dan organisasi lainnya di berbagai negara di seluruh dunia. Google Map Maker memungkinkan pengguna untuk bersama-sama mengembangkan dan memperbarui pemetaan layanan di seluruh dunia (Wikipedia, 2016).

Tampilan satelit Google Maps adalah "top-down". Sebagian besar citra resolusi tinggi dari kota adalah foto udara yang diambil dari pesawat pada ketinggian 800 sampai 1.500 kaki (240460 meter), sementara sebagian besar citra lainnya adalah dari satelit. Sebagian besar citra satelit yang tersedia adalah tidak lebih dari tiga berusia tahun dan diperbarui secara teratur.[4] Google Maps menggunakan varian dekat dari proyeksi Mercator, dan karena itu Google Maps tidak dapat secara akurat menunjukkan daerah di sekitar kutub.

Google Maps untuk seluler dirilis pada bulan September 2008. Pada Agustus 2013, Google Maps bertekad untuk menjadi aplikasi yang paling populer di dunia untuk ponsel cerdas, dengan lebih dari 54\% dari pemilik ponsel cerdas di seluruh dunia menggunakannya setidaknya sekali. Model pelestarian yang dimaksudkan dalam penelitian ini adalah upaya untuk memberikan pengetahuan terutama tentang keberadaan peninggalan sejarah dan cagar budaya di Kota Semarang. 


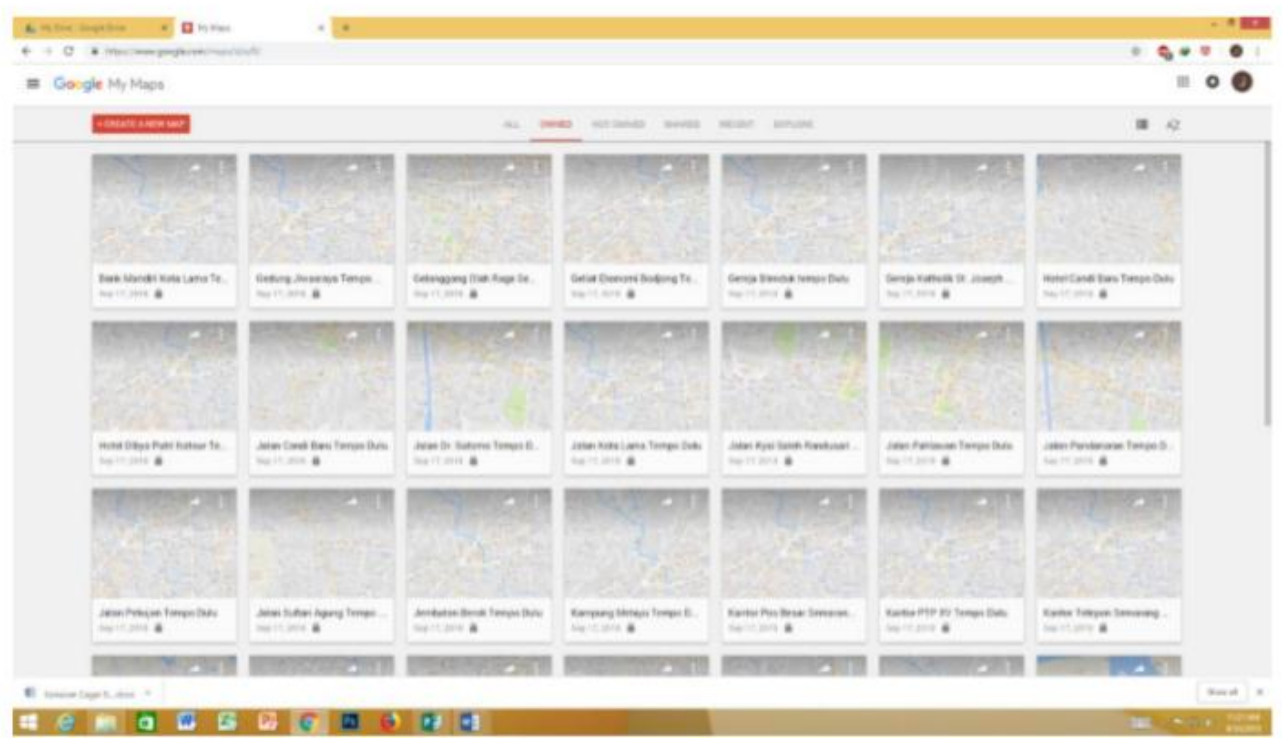

Gambar 1.1. Tampilan Peninggalan Sejarah yang telah tersimpan di Google Maps

Di dalam Google maps, peneliti memberikan informasi terkait dengan peninggalan atau cagar budaya yang ditandai. Berikut adalah contoh penggambaran pada titik lawang sewu.

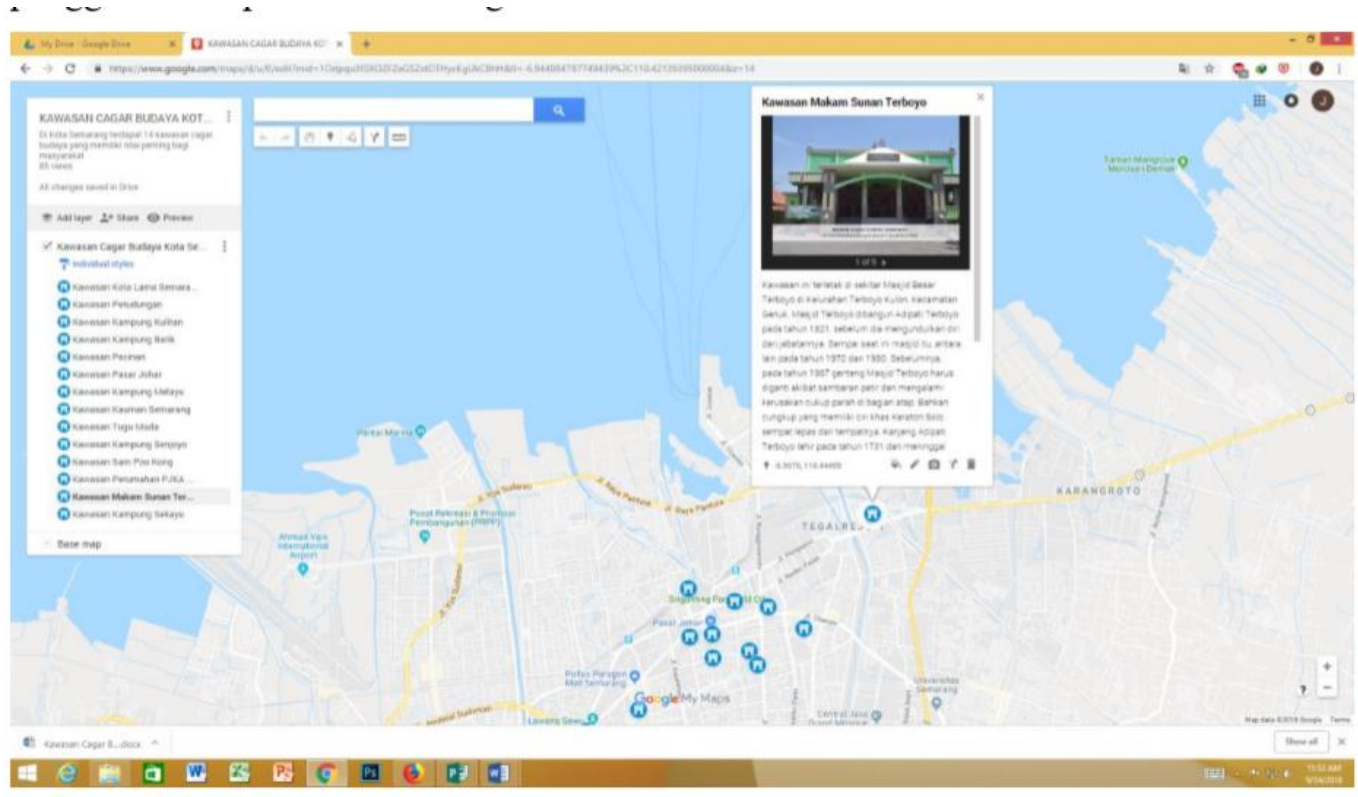

Gambar 1.2. Tampilan salah satu peninggalan sejarah yang sudah ditandai di dalam Google Maps 
Melalui pemanfaatan google maps diharapkan masyarakat lebih familiar dan mudah dalam mengakses informasi terkait dengan peninggalan kesejarahan yang ada di Kota Semarang.

\section{Simpulan}

Benda Cagar Budaya di Kota Semarang sebanyak 328 buah meliputi bangunan sosial budaya seperti sekolah, bangunan kesehatan/rumah sakit, kantor pos dan kantor pelayanan, gedung serba guna, stasiun, museum, lain-lain. Selain itu ada pula bangunan keagamaan, seperti masjid/mushola, gereja, serta klenteng. Ada pula bangunan yang termasuk dalam bangunan usaha seperti perkantoran, pabrik dan gudang, hotel/penginapan, gedung pertemuan, restoran, serta pasar. Namun demikian, banyak pula bangunan cagar budaya yang termasuk dalam bangunan hunian serta bangunan khusus, seperti reservoir, gerbang, gardu listrik, taman dan sebagainya. Saat ini, Kota Semarang memiliki 14 kawasan cagar budaya. Ke empat belas kawasan tersebut meliputi, (1) Kawasan Kota Lama; (2) Kawasan Petudungan; (3) Kawasan Kampung Kulitan; (4) Kawasan Kampung Batik; (5) Kawasan Pecinan; (6) Kawasan Johar; (7) Kawasan Kampung Melayu; (8) Kawasan Kampung Kauman; (9) Kawasan Tugu Muda; (10) Kawasan Kampung Senjoyo; (11) Kawasan Sam Po Kong, (12) Kawasan Perumahan PJKA di Kedungjati; (13) Kawasan Makam Sunan Terboyo; dan (14) Kawasan Kampung Sekayu. 2. Upaya pengembangan model konservasi cagar budaya dilakukan dengan menguatkan aspek pengetahuan masyarakat. Dengan demikian, penguatan konservasi diterapkan dengan berbasis literasi informasi. Penguatan ini dilakukan dengan mengintegrasikan informasi kesejarahan di aplikasi Google Maps. Penggunaan Google Maps dilakukan agar masyarakat dengan mudah mengakses informasi kesejarahan dan arti penting cagar budaya di Kota Semarang.

\section{DAFTAR PUSTAKA}

Amin, dkk. 2011. Repository Model for Intangible Heritage “The Malay Scenario”. Proceeding of the International Conference on Advanced Science, Engineering and Information Technology 2011 Hotel Equatorial Bangi-Putrajaya, Malaysia, 14 - 15 January 2011.

Amsyah, Zulkifli. 2000. Manajemen Sistem Informasi. Jakarta: PT Gramedia Pustaka Utama. Hastuti, Khafiizh \& Erwin Yudi Hidayat. 2014. "Purwarupa Tangible Cultural Heritage Kategori Cagar Budaya Tak Bergerak Berbasis Database Multimedia”. Prooceding. Seminar Nasional Teknologi Informasi dan Multimedia, Yogyakarta, 8 Februari 2014 
Hendro, Eko Punto. 2015. "Pelestarian Kawasan Konservasi di Kota Semarang." Jurnal Konservasi Cagar Budaya Borobudur, 9(1). Hlm. 17-28

Tobing Warella \& Purnaweni 200). Studi Implementasi Kebijakan Pemerintah Kota Semarang Dalam Upaya Melestarikan Bangunan Cagar Budaya Di Kota Semarang. Dialogue, $5(1)$.

Indrajit. 2001. Analisis dan Perancangan Sistem Berorientasi Objek. Bandung: Informatika

Jogiyanto HM. 1995. Analisis dan Desain Sistem Informasi: Pendekatan Terstruktur Teori dan Praktek Aplikasi Bisnis. Yogyakarta: Andi Offset.

2005. Sistem Teknologi Informasi. Yogyakarta: Andi

Mahyuzir, Tavri D . 1997. Analisis dan Perancangan Sistem Pengolahan Data. Jakarta: PT Elex Media Komputindo.

Meyer, E, P. Grussenmeyer, J.P. Perrin, Anne Durand, Pierre Drap. A web information system for the management and the dissemination of Cultural Heritage data.. Journal of Cultural Heritage, Elsevier, 2007, 8 (4), pp.396-411.

Tanudirdjo, Daud A. 2003. "Warisan Budaya untuk Semua: Arah Kebijakan Pengelola Warisan Budaya Indonesia di Masa Mendatang”. Makalah. Disampaikan dalam Kongres Kebudayaan V di Bukittinggi, 20-22 Oktober 2003.

Tjandrasasmita, Uka. 2010. "Pelestarian Benda Cagar Budaya dan Pemanfaatannya bagi Pembangunan Bangsa”. Suhuf, 3(1). Hlm. 131-143.

Widiastuti, Eko Heri. 2014. "Revitalisasi Benda Cagar Budaya Di Kota Semarang”. Majalah Ilmiah Pawiyatan, 21(2). Hlm. 1-11. 